HStud 25 (2011)2, 287-302

DOI: 10.1556/HStud.25.2011.2.9

\title{
DANCING ON THE EDGE OF A VOLCANO: EAST EUROPEAN ROMA PERFORMERS RESPOND TO SOCIAL TRANSFORMATION
}

\author{
LYNN HOOKER \\ Indiana University \\ Bloomington, IN, USA
}

\begin{abstract}
The advent of a more open society in Eastern and Central Europe has created space for political and cultural freedoms unthinkable under state socialism, particularly for the Roma (Gypsy) minority. The years since the change of regime have revealed apparently insatiable appetites for "Gypsiness" among consumers, impresarios, and recording companies, and artists from the East Bloc, many of them from extremely modest backgrounds, have filled niches in the business of sating those appetites. Yet for many Roma in the region, the political changes of twenty years ago have been disastrous: the end not only of full employment and a robust social safety net but also of the limitations on free speech and rigidly enforced state monopoly on violence that hid racial tensions under a veil of oppression. This paper addresses the contrast between the conditions of the Roma population at large with the successes of a handful of successful musicians. It also considers the ways some musicians in Hungary are working to improve both the conditions for Roma and the perception of Roma by non-Roma in and out of the region.
\end{abstract}

Keywords: Roma (Gypsies) - Eastern Europe, popular music, marginality

The advent of a more open society in Eastern and Central Europe has created space for political and cultural freedoms unthinkable under state socialism, particularly for the Roma (Gypsy) minority. Roma musicians in particular have benefitted from this greater openness, as the twenty years since the change of regime have revealed voracious appetites for "Gypsiness" among consumers, impresarios, and recording companies, and artists from the East Bloc, many of them from extremely modest backgrounds, have filled niches in the business of sating those appetites. They have also taken this new atmosphere as an opportunity to innovate stylistically and to collaborate with musicians from many backgrounds.

This essay is "advertised", if you will, under a stolen title: the phrase "Dancing on the Edge of a Volcano" is taken from Peter Gay's book Weimar Culture: The Outsider as Insider (1968), a book that addresses a very different period in European history. Despite the very different time period and topic, the passage in 
which this phrase originally appears offers provocative parallels to the present-day situation. I quote:

\begin{abstract}
The excitement that characterized Weimar culture stemmed in part from exuberant creativity and experimentation; but much of it was anxiety, fear, a rising sense of doom. [...] it was a precarious glory, a dance on the edge of a volcano. [...] the creation of outsiders, propelled by history into the inside, for a short, dizzying, fragile moment (Gay 2001 [1968], xiv).
\end{abstract}

To observe the emergence of a mass of Roma performers, particularly popular musicians, in recent decades is not only to note the "outsiders propelled by history into the inside" but also to wonder, given the conditions affecting the Roma population at large, whether this can last, or whether it is only a "short dizzying fragile moment". For many East European Roma, the transformations of the post-1989 era have brought only the end of stability (in the form of full employment and a robust social safety net) and of state protection from openly racist language and acts. The extremes of anti-Roma sentiment are highlighted by the trials pending in the European Court of Human Rights over the forced sterilization of several Slovak Roma women (Puppinck, 2011); by the murders of six Roma in Eastern Hungary in 2008 and 2009, for which defendants went on trial in March 2011 (Cigányvadászat-per, 2011); and the conflict between the Roma citizens of the village of Gyöngyöspata and the right-wing "Civil Guard Association for a Better Future" (Szebb Jövőért Polgárőr Egyesület) who are "patrolling" in their neighborhood (European Roma Rights Center 2011, Hungarian Ambiance, 2011). What I offer here is a preliminary consideration of this juxtaposition between the dire conditions of the Roma population at large and the successes of a handful of successful musicians.

\title{
Gypsiness
}

Roma musicians have long been intertwined with the entertainment music through Europe, especially Central and Eastern Europe; they have played professionally for non-Roma as well as Roma in cafés, restaurants, and theaters, and at life-cycle and calendrical celebrations (weddings and baptisms are examples of the former, New Year's and Easter of the latter). This role, "primarily male and instrumental [though sometimes also vocal], requires Roma to know expertly the regional repertoire and interact with it in a creative manner" (Silverman, 2007, 338). The music played by professional Romani musicians varies widely by region; public recognition of the Romani role in its performance also varies. Hungary's "Gypsy music", labeled according to the ethnicity of its performers, is the extreme 
case. This genre arose in the mid-nineteenth century and remained popular well into the twentieth, and even now it maintains a presence in the Hungarian soundscape (see Sárosi, 1978 among others). As a worldwide popular phenomenon, "Gypsy music" dates from the early 1990s for two reasons. First, the fall of the Iron Curtain meant that many musicians who had been prohibited from traveling were now allowed to leave their home countries. Second, the documentary Latcho drom (Good road) (released in 1993), directed by French (half-Romani) filmmaker Tony Gatlif, in combination with the fiction films of Yugoslav filmmaker Emir Kusturica, "initiated a veritable 'craze' for Gypsy music in the [...] world music scene" (Silverman, 2007, 339), which itself grew exponentially during the 1990s. As an associated phenomenon, the Spanish-French music group the Gipsy Kings were on top of Billboard magazine's World Music charts for six out of the first seven years that the magazine tracked World Music as a separate category, beginning in 1990 (Taylor, 1997, 7).

We can track the international "Gypsy music craze" through the ensuing years via festivals, both of "world music" and specifically "Gypsy music", and through recordings. The Lotus Festival of World Music and Arts in Bloomington, Indiana, offers a convenient lens through which to view the use of "Gypsiness" on the Western festival stage. "Gypsy music" has been a popular draw at Lotus for years, represented by artists coming from India, Spain, and many points in between. Some of those artists are clearly Roma, for example the Szászcsávás Band (from a Hungarian-speaking region of Romania) and Kal (from Serbia). Others are clearly not: for example members of Balkan Beat Box, a local favorite, are Israelis living in New York, but they play repertoire associated with Roma artists, especially from the Balkans. In a few cases, like Hungary's Kis tehén (Little Cow), most of the repertoire is not clearly sonically marked as "Gypsy" but a subset of the personnel are Roma, and whoever is writing the publicity for the group chooses to stress its "Gypsy-tinged" sound (Yonas Media, 2011).

Festivals featuring "Gypsy music" exclusively have also taken a prominent role in popularizing these artists. These began to take off in the West in the early 1990s, around the time of the film Latcho drom, in Germany, France, Italy, Switzerland, and the UK, among others. The first North American "Gypsy festival" was the Gypsy Caravan tour in spring 1999; "due to its resounding success, a second [Caravan] tour followed in fall 2001" (Silverman, 2007, 340). New York established an annual "Gypsy festival" in 2005. Eastern European impresarios have also jumped on this bandwagon; there are notable recurring events in Prague, Budapest, Skopje, and Stara Zagora, Bulgaria (Silverman, 2007, 339).

Finally, we can see the growth of a "Gypsy music" sector in the recording industry, a real or virtual bin in a record store (see also Malvinni, 2004, 207-14). An incomplete listing of compilation albums featuring diverse Romani artists includes Road of the Gypsies (1996), Zingari: Route of the Gypsies (1997), The 
Rough Guide to the Music of the Gypsies (1999), Gypsy Caravan (2001), and Children of the Wind (2001); their covers show a wide array of Romanticized imagery. Compilations of localized genres of "Gypsy music" or by individual groups push this process even further, as in the titles and covers of compilation Gypsy Magic: Nouveau Flamenco (2001), Band of Gypsies by Les Yeux Noirs of France and Taraf de Haïdouks of Romania (1992 and 2001, respectively), and Taraf's Honourable Brigands, Magic Horses and Evil Eye (1994). The extent to which musicians and the music industry recognize "Gypsiness" as an effective "hook" (whether for marketing or aesthetics or both) shows itself in extremis in Ensemble Caprice's series of recordings titled The Baroque Gypsies, featuring compositions by Vivaldi and Telemann interspersed with arrangements of melodies from the Uhrovska Collection, an eighteenth-century manuscript "featuring single-line violin melodies in several hands that represent a compendium of contemporary practices" - whether or not there is any clear evidence that these composers knew them (Beckerman, 2009). Musicologist Michael Beckerman states that while

\footnotetext{
There is no doubt that the [Roma] are implicated in the Uhrovska collection in some way [...] [but] nothing is certain [...] The marketing of something as Gypsy music usually implies an erotic blend of expressivity and virtuosity that one doesn't always associate with, say, the German Baroque. It is why [...] music as disparate as punk, flamenco and hip-hop are marketed as 'Gypsy': Gypsy music sells (Beckerman, 2009).
}

What does it sell? In Bulgaria and Romania, orientalism is central to two popular genres, Bulgarian chalga and Romanian manele, also known as muzica oriental; Roma performers are among the biggest stars in both genres, and along with these "exotic" performers, the vocal style and belly-dance inspired movements also rely on "Oriental" allure. The usual gendered provocations of orientalism are bent further and to great effect by cross-dressing Bulgarian Roma superstar Azis (Markoff, 2006).

In Hungary, too, Roma performers have an outsized presence in popular music. Radio, music video, and reality TV have overtaken the restaurant as the most important site for contemporary "Gypsy music". In the first season of Megasztár, the unlicensed Hungarian version of American Idol and Pop Idol, ending in spring 2004, the runner-up, Ibolya Oláh, and third-place finisher, Laci Gáspár, were Roma; the winner of the second (2005) season, Ferenc Molnár, was also, as indicated by his stage name, "Caramel" (Munk, 2007). These performers' "play between Hungarian and Roma identities is often understated, or as Anikó Imre puts it 'whitewashed and nationalized, with the singer[s'] voluntary participation"” (Imre, 2009, 124). An even bigger and more problematic media personality is 
Győző Gáspár, front man for the group Romantic turned star of the RTL Klub's Gyözike, which began in 2005. Gyözike is a "reality comedy" that follows Gáspár's family life, much in the vein of The Osbournes on America's MTV network. Non-standard speech from the patriarch is a source of humor in both, but where Ozzy Osbourne's speech is muddled by the aftermath of years of substance abuse, Gáspár's "speech impediment” is a thick Palóc accent. Anikó Imre's assessment captures the show's problems succinctly:

\begin{abstract}
While the fact that a Romany man and his family occupy a precious prime-time television slot and attract a large non-Roma audience is a significant development [...] The décor is in bad taste, family members constantly shout at one another in the stereotypical Roma dialect familiar from cabaret scenes, and most of Gáspár's efforts to assert himself backfire in one ridiculous way or another. The program seems to confirm nothing but Gypsies' inability to function as hardworking citizens (Imre, 2009, 126).
\end{abstract}

\title{
Post-Socialist Roma in Crisis: Employment, Poverty, and Education
}

The other dominant image of Roma in the media twenty years after the change of regime could hardly be more different from such flashy images of pop stars: an image of extreme poverty, with its association with an "inability to function" and concomitant social exclusion. That image reflects an unfortunate reality: that everyday life for many of Eastern Europe's Roma population has deteriorated over the course of this period, which has seen not only massive unemployment and entrenched residential and educational segregation but also flare-ups of violence.

According to several metrics - literacy and infant mortality, to name two important ones - the lives of Roma improved substantially under state socialism; state socialist policies had almost eliminated the disparity between non-Roma and Roma employment rates by the late 1980s (Barany, 2002, 139, 173), and employment brought with it some economic and social inclusion. The price of these improvements was assimilation, and in some countries assimilation pressures were very severe. In Czechoslovakia, use of the Romani language was banned in schools, Roma were dispersed from concentrated settlements and scattered among urban housing estates, and most controversially, women were offered financial incentives to be sterilized; many were sterilized without full informed consent, a practice that allegedly continues (Puppinck, 2011). In Bulgaria, not only the Romani language but also Romani-style dancing and musical instruments associated with Roma were banned, and officially Bulgaria had no more Roma or other non-ethnic Bulgarian citizens after the mid-1970s (Barany, 2002, $115,117-18)$. 
Hungary and Yugoslavia, meanwhile, put into place much more positive policies, particularly from the 1970 s on. In certain contexts, at least, ethnic discrimination was sanctionable: a clarinetist in a Budapest restaurant band related that musicians could report employers who called them "dirty Gypsies" to Party authorities. Hungary supported Gypsy intellectuals, allowing the use of Romani as the language of instruction in some schools, and also allowed cultural groups and music ensembles (Barany, 2002, 121-3). Most prominent were the "Roma folklore ensembles" who made the case for their repertoire being "authentic" rural folklore in the same vein as the repertoire of the táncház. The acceptance of these groups was hard-won: founding members of some of these ensembles tell of the difficulty they had getting invited to perform, and when eventually these ensembles were accepted enough to stage their own festival, police patrolled both the audience and the stage heavily (Lange, 1997, 16). Eventually, though, these folklore groups became a vector for legitimizing Roma aesthetic expression, and the public acceptance of such expression

\section{[...] helped introduce the idea, which was later codified in Hungary's 1993 law on minorities, that Roma have claims and status equal to that of other ethnic minorities. [...] Many of the Roma who became active in drafting legislation, negotiating with political parties, speaking to the press on Roma issues, and serving as elected repre- sentatives were indeed the leaders of folklór groups (Lange, 1997, $23,14)$.}

Thus cultural legitimacy gained during the socialist era combined with the integration of Roma into the socialist-era economy brought with it a hopeful degree of political inclusion at the time of the change of regime.

But the period of transition also saw devastating economic changes among the Roma in the region, who were concentrated in the socialist era in jobs in heavy industry, mining, steel, and construction, the sectors of the economy where post-socialist de-industrialization resulted in the most severe job losses. Where jobs and housing were linked, many also lost their apartments. The economic collapse of many Roma communities without the jobs provided by the "distorted modernization of socialism" revealed "the assumed integration of Roma into Hungarian society [...] to be a mere illusion" (Vajda and Dupcsik, 2008, 7). While Roma incomes and literacy improved in absolute terms in the socialist era, they were still relatively poor and ill-educated; the end of socialist assimilation policies meant the end of policies that had led to these improvements. Rates of poverty, whether measured based in substantive terms like hunger or in relative terms - whether Roma are more poor than their non-Roma compatriots - have gone up significantly. This is particularly true among the very poor (Ladányi and Szelényi, 2006, 158). Moreover, compared to poverty under state-socialist full employment, 
post-socialist poverty is "deeper and lasts longer"; residential segregation, exclusion from the labor market, and inadequate education reinforce each other and may be passed on to succeeding generations (Ladányi and Szelényi, 2005, 130; Ladányi and Szelényi, 2006, 173, 176). A small stratum of Roma-mostly urban (and there are significantly more urban Roma now in the East Bloc than there were at the middle of the twentieth century) - have been able to move up into a middle-class existence, but very poor Roma are often excluded geographically, educationally, socially, and politically as well as economically. They may be barred from public accommodations and infrastructure ranging from shops and restaurants to mainstream schools to running water (Harper, Steger and Filčák, 2009). In Csenyéte, a village in northeast Hungary that János Ladányi and Iván Szelényi examined over time, the population went through waves of integration and assimilation - in both the middle of the nineteenth century and the state socialist era - followed by retrenched segregation, in the late nineteenth to early twentieth centuries and since the 1980s. The latter wave of segregation has been largely voluntary; not only non-Roma but also more ambitious Roma have left the village in search of better opportunities, resulting in a completely Roma, completely impoverished settlement:

\footnotetext{
Class forces differentiate Romany society, with the better-to-do, upwardly mobile, more ambitious Roma leaving the ghetto and leaving behind only those who cannot escape. [...] the Romany ghetto poor [...] are not only separated from [non-Roma] society and from the better-to-do Roma, but are now excluded from the economic system. They are not at the bottom of the system, they are outside it (Ladányi and Szelényi, 2003, 49).
}

The authors argue that rather than being simply "poor", then, this growing group of very poor Roma constitute an "underclass", a group that becomes increasingly trapped in a cycle of poverty. They lack social as well as economic capital; the culture of such communities generally lacks the tools for getting out of poverty. The concept of an underclass, proposed in the late 1970s by William Julius Wilson and elaborated by him and others in the ensuing years, began as a way to understand the development of "truly disadvantaged" urban African-American communities that developed when, after the end of legal segregation of housing, areas like Harlem in New York or the South Side of Chicago were abandoned by anyone who could leave (Wilson, 1987; Small, Harding and Lamont, 2010). Ladányi and Szelényi argue persuasively for the parallels between the socio-political shifts that allowed many African-Americans to leave the ghettos behind and the even more dramatic shifts that put so many people in motion in Eastern Europe after 1989. 
Comparative studies from EDUMIGROM, the project led by Júlia Szalai of Central European University on the educational experiences of Roma and migrant students in nine member states of the European Union, include both isolated rural Roma settlements, the types of Roma communities that have dominated media discourses on the "Gypsy problem" in Hungary in recent years, as well as "mixed Roma and non-Roma neighbourhoods in deteriorated and economically collapsed Central European cities, where the common denominator of inhabitants is deep poverty and social exclusion" (Szalai et al., 2010, 158). While these very poor communities do not constitute the majority of Roma by any means, they are growing due to high birth rates, and they also play a disproportionate role in the image many have of the Roma.

Education is obviously central to any attempts at improving conditions, but ongoing studies show how ethnic segregation in education frequently perpetuates social exclusion. In destitute areas like Csenyéte, schools are

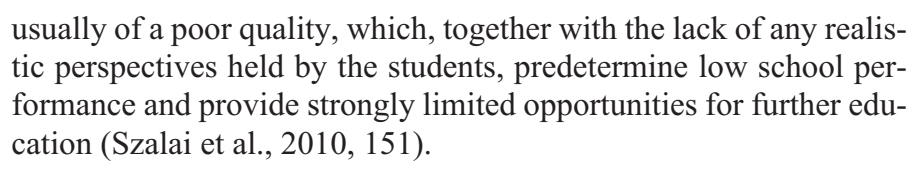

When Roma children live near a variety of school options, however, they are still disproportionately steered to "special education" schools or to tracks within mixed schools that provide

\begin{abstract}
a limited curriculum and a rather poor quality of teaching and do not render transferable knowledge for applying to other types of secondary education - consequently, these programmes often develop into segregated and self-contained forms of schooling that neither provide graduation, nor facilitate later attempts at catching up (Szalai, 2008, 6).
\end{abstract}

Moreover, in communities with substantial numbers of Roma students, "recurrent processes of "white flight"" may turn schools that are open to those students

[...] into designated "minority" institutions. As such, these schools hardly can escape the usual concomitants of declining quality in teaching, high turnover of the teaching staff, a sinking reputation, and a self-sustaining flight of all those - both from the majority and the ethnic minorities - who have the energy and the contacts to search for other, better schools for their children (Szalai, 2011, 37).

Despite the fact that students and parents both know that schooling is the only chance for students to leave behind their marginalized conditions and "aspir[e] for meaningful integration into society-at-large", then, schools often end up deepen- 
ing the distinctions between majority youth and their "othered" peers and perpetuating the social exclusion of the latter - unless local educational and municipal leadership and innovative teachers dedicate themselves to fighting this process. Such exceptional efforts can only begin to fight against the prevailing current of ethnic and social marginalization (Szalai et al., 2010, 174).

In the difficult conditions of East European Roma ghettos, it is no wonder that an illegal shantytown in France or Italy might look good by comparison - and many of the remaining go-getters have traveled to seek out work. The French government's effort to dismantle these shantytowns and deport their residents in the summer of 2010 highlighted the visceral rejection by many in the West of the freedom of movement promised by the Western ideals embodied in the European Union. Incidentally, France attempted to deport employed as well as unemployed Roma migrants in France - among them musicians playing with the Cirque Romanès, a Parisian "Gypsy circus" that represented France at the World Expo in Shanghai in June 2010 (Davies, 2010). Such facts highlight the colonial structures using Roma performers: what is expected is that the Roma will "wait at the margins of Europe (or in western European ghettos) to be discovered by white promoters; they are then escorted to the West, briefly put on stage, and escorted home" (Silverman, 2007, 342).

\section{Political Mobilization of Roma in Eastern Europe, Its Successes and Failures, and the Role of Performers}

Some see the development of a "Gypsy music-industrial complex" as "dancing on the edge of a volcano" in the worst sense: this complex "cleanse[s], tame[s], appropriate $[\mathrm{s}]$ and colonize $[\mathrm{s}]$ the exotic" while absorbing money and attention that, in their view, could be better spent on "real issues" and "real activism" (Silverman, 2007, 342, quoting Ian Hancock). In fact Roma activists in recent decades have mobilized to engage governments and the majority public in an effort to improve both perception of and conditions for Roma at large. Such activism has succeeded in attracting the attention of national and international organizations and in changing the terms of the debate, most obviously by gaining legitimacy for the term "Roma" as preferred politically correct ethnonym. Still, notwithstanding the progress Roma activists have achieved, they "have manifestly failed to mobilize the Roma into a political mass movement", even into a more accurate count of Roma population in national censuses (Vermeersch, 2006, 2). Moreover, mass discourse has arguably seen a backlash against Roma with promotion by Roma activists and non-Roma elites of minority-rights discourses.

In this context there is a need not only for interventions to address the concerns of specific marginalized individuals, schools, or communities but also for a redou- 
bling of efforts to change public discourse. Sociologist Júlia Szalai concludes her team's study of migrant and Roma students, schools, and communities by stating that

\begin{abstract}
It is the coordinated policies toward (re)establishing the foundations of multiculturalism as much on the level of political representation as in the day-to-day relations within the communities that might provide the framework and the conditions for schools to attain the still widely-held goals of equal opportunity, equity, and colour-blind inclusion in education (Szalai et al., 2010, 174).
\end{abstract}

In the context of a less-than-stellar record by "real activists", performers must continue to play an important role. Music is an area in which the particular and distinctive characteristics of Roma have sometimes worked in their favor, though only in the context of heavy controls, both on their presentation and on their physical movements, as described earlier, so as to proscribe any real or imagined negative impact that they may exert. On and off stage, performers can play on their image as "an immutable, archaic, traditional, arcane, secluded and 'unconstructed' ethnic group [...] marked by a set of particular, distinctive [...] characteristics" (Vermeersch, 2006, 3) while at the same time arguing for improved conditions, improved ethnic pride, and the development of multiculturalism on every level of society. A number of current projects and institutions use "Gypsiness" implicitly or explicitly to address the role of Roma in schools and society. The remainder of this essay discusses three of those projects in Hungary.

The first project is the development of bilingual (Hungarian and Romani) music-curriculum materials, recording songs and producing accompanying songbooks in both languages. This project, Roma müvészek a gyerekekért: Népdalok, megzenésitett versek óvodásoknak és kisiskolásoknak (Roma artists for the children: Folksongs and poems with music for young children) was co-curated by István Szilvási, activist and leader of the Szilvási Gipsy Folk Band, and (non-Roma) ethnomusicologist Katalin Kovalcsik of the Institute for Musicology (Budapest, 2005). There have been several projects to develop curricular materials featuring Roma songs in recent years; this one stands out because of the participation of top-flight Hungarian Roma recording artists recruited by Szilvási.

The next project in terms of the age of its target audience is the network of schools developed by Kalyi Jag (Black Fire), the pioneering "Roma folklore" ensemble founded in the late 1970s. The Kalyi Jag schools in Budapest, Miskolc, and Kalocsa require Roma students to master "useful modern" subjects alongside a grounding in Roma language and culture (Kalyi Jag, 2008), following a model for minority education championed by some in the West (see e. g., Ogbu Family, 2003). Advocates of multicultural education see the inclusion of knowledge about the histories, cultures, and contributions of diverse groups - in this case, Roma 
topics in particular - in the curriculum as critical in keeping students engaged in and empowered through the educational enterprise. Schools for Roma students only like the Kalyi Jag Schools do not and cannot aim to serve the entire Roma school-age population, and in Hungary, as elsewhere, there is a debate over whether segregating disadvantaged minority students from the majority is the best solution, especially long-term. Leaders of such institutions argue, though, that such schools provide a superior learning environment for Roma students "since they can freely adapt their methodologies to [...] children's culture, background, and social skills" (Barany, 2002, 319). The Kalyi Jag schools understand this goal as at once educational, cultural, and political: their "Institutional Quality Assurance Program" (Intézményi Minőségbiztosítási Program) states as their goal not only the preparation of students for a trade or the érettségi (Matura, the exam required for students who seek university education), but also their nurturing as moral individuals, citizens, and representatives of their race: "We must show them that at all times they have worthy examples who present preeminent achievement in Roma culture, public life, and politics" (Kalyi Jag, 2008).

The above two examples show Roma musicians' investment in education of youth and the use of music and performance in furthering that education. From the point of view of public discourse, Roma performance can be and is an important tool both in developing Roma leadership and in educating the public, both Roma and non-Roma. Probably the highest profile events are festivals of "Gypsy music", and Budapest's Athe Sam!/Itt vagyunk! (We are here!) Roma Arts Festival is a particularly potent case. This annual festival was first staged in 2007, organized by a committee of Roma and non-Roma, older and younger; two Roma musicians, István Szilvási and Antal Kovács, led the programming. The week-long event includes musical acts in a wide variety of genres, "authentic" and "modern", and of non-musical events - film screenings, art exhibitions, theatrical performances, artisan demonstrations, and panel discussions on current issues, from definitions of Roma ethnicity and traditional culture to education and the role of Roma in the political arena. Significantly, the site of the festival, the Gödör Klub, is at the center of Pest. The audience is multi-ethnic and international by design: the intent from the beginning has been to draw backpacking tourists as well as locals, and in subsequent years, programming decisions have been guided in part by the desire to increase international attendance.

The multi-ethnic and international shape of the event also appeals to the respect for minority rights mandated in Eastern Europe by international governmental organizations like the United Nations and the European Union. These ideals and their international public are implicit in the online note "About the Festival':

The purpose of the Festival is to provide a framework for inter-cultural dialogue through art; to contribute to the mitigation of misun- 
derstanding and to promote human dignity. What is at the heart of all this is knowledge and information. [...] Highlighted features of the Festival will be the joint productions of Roma and non Roma artists, as well as providing a forum for new talents; we will provide the opportunity for civil organisations and individuals to present their model initiatives; and through organising roundtable discussions, we seek to contribute to empowering the Roma community to effectively carry out interest representation. Last year represented an important stage in the history of Athe Sam: in 2010 we started cooperating with a great number of festivals both in Hungary and abroad with the aim of promoting the values of social inclusion both domestically and in other countries (Athe Sam, 2011).

This statement conveys these values in a largely positive sense, barely suggesting who their opponents might be. The Gödör Klub also acted as one of the major venues for Zene a Rasszizmus Ellen (Music Against Racism), an organization formed in cooperation with the British Embassy and the British NGO group Love Music Hate Racism in August 2009, around the same time that the "Gypsy hunters" killed their sixth victim (Zene a Rasszizmus Ellen, 2009; Népszabadság Online, 2011). Such events brought together Roma and non-Roma performers, and with them Roma and non-Roma audiences, rallying for a multi-cultural vision of Hungarian society.

The organizers of the Athe Sam festival, Gödör Klub, and the Kalyi Jag schools have worked to reconfigure "Gypsy music" in its many manifestations as more than something to entertain the majority through expressivity, virtuosity and exoticism. In their hands it is also a forum through which to engage the public in a dialogue about the place of Roma, and the relationships between Roma and non-Roma, in contemporary Europe. The multi-layered approach of the Athe Sam festival especially sets it apart from many "Gypsy" events through its deliberate positioning of Roma, emphatically including Roma performers, as actors in a rational public sphere, that "theater in modern societies in which political participation is enacted through the medium of talk", which according to Jürgen Habermas, his followers, and his critics, "is indispensable to critical social theory and to democratic political practice" (Fraser, 1990, 57).

The public for "Gypsy music" in Hungary has historically been understood to be non-Roma; Hungarians hired Roma to perform their entertainment music, the story goes, because being a professional musician was historically viewed as an unreliable, unrespectable, or immoral way to make a living, but the publics that these musical genres defined for the majority - restaurants, clubs, theaters, village weddings, and dance halls rural and urban - were and are nonetheless understood as ethnically Hungarian. The contemporary popular music in Hungary also gener- 
ally assumes a Hungarian public. Although the racial/ethnic identity of the "Gypsy musician" has been essential to its success in "exteriorizing the state of the soul" of the Hungarian audience member, "Gypsiness" has been assumed to be primarily an instrument of non-Roma discourse (van de Port, 1999, 291, citing Block, 1936; see also Sárosi, 1978).

By contrast, the Roma public culture created by contemporary performers constitutes an open dialogue between Roma and non-Roma, locally and globally. Roma public culture creates a "zone of cultural debate [...] an arena where other types, forms, and domains of culture are encountering, interrogating and contesting each other in new and unexpected ways" (Appadurai and Breckenridge, 1988, 6). In this context, any music Roma musicians perform, from the most "Hungarian" (magyar nóta and Transylvanian Hungarian folkdance music) to the most "authentically Roma" ("folklore" singing in the Romani language) to music in international genres (pop, rap, jazz, punk), is political. A forum like the Athe Sam festival makes the political nature of performance explicit.

The potential impact of such performance is difficult to gauge. A skeptic might conclude that "mere" performance will only change no minds; those who most need to "hear" the message of understanding and tolerance are those least likely to hear it. We might look for hope to the contrary in Michael Warner's idea that

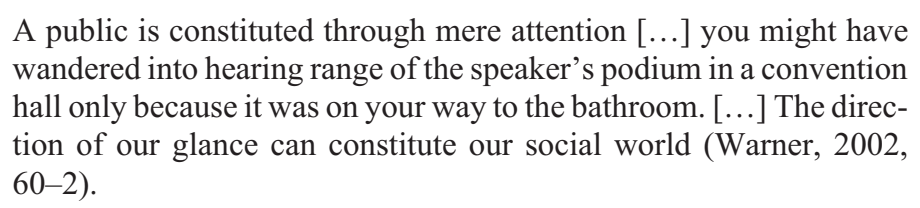

Here Athe Sam's choice of venue and mix of activities might further its cause. Held steps away from the hub of the city's transportation network, not only inside the Gödör Klub but also on its outdoor plaza, with free admission, the festival is ideally situated to draw in the casual passer-by. In this context "Gypsy music" acts not only as an abstract exotic concept to entice potential attendees but also as a sonic lure to the ear.

It requires a substantial leap from being a haphazard or oppositional member of this public to undergoing a lasting change through the experience of such communicative acts. Nonetheless, lasting changes in public discourse on Roma in Eastern Europe are even more unimaginable without activities like Athe Sam. The leadership of musicians and performance promoters in using the power of "Gypsiness" to shift the public dialogue on the "Roma question" will be essential to furthering the social inclusion of Roma in the region. 


\section{Works Cited}

\section{Bibliography}

Appadurai, Arjun and Carol A. Breckenridge (1988) 'Why Public Culture?' Public Culture: Bulletin of the Project for Transnational Cultural Studies, Vol. 1, No. 1, 5-9.

Athe Sam (2011) 'About the Festival. Athe Sam!! - Itt vagyunk!!' (We are here!!) (Budapest: Gödödr Klub). Available at: http://www.athesam.hu/fesztival (Accessed April 10, 2011).

Barany, Zoltán (2002) The East European Gypsies: Regime Change, Marginality, and Ethnopolitics (Cambridge, UK: Cambridge University Press).

Beckerman, Michael (2009) 'Exploring Bach for His Gypsy Side' New York Times (November 8), AR25. Available at: New York Times Online, http://www.nytimes.com/2009/11/08/arts/music/08beck.html (Accessed July 6, 2011).

Block, Martin (1936) Moeurs et Coutumes des Tziganes (Paris: Payot).

Cain, M. Celia (Forthcoming) Native Resonance: Native American Popular Music in the Shadow of Colonialism (Jackson, MS: University Press of Mississippi).

“Cigányvadászat-per” (Gypsy-hunting Trial). Available at: http://ciganyvadaszat-per.blog.hu/ (Accessed August 10, 2011).

Davies, Lizzie (2010) 'Gypsy circus is next on France's expulsion list: After deporting many illegal Roma immigrants, Nicolas Sarkozy’s government may force Europe's only Gypsy circus to close down' The Guardian (September 26th) http://www.guardian.co.uk/world/2010/ sep/26/roma-gypsy-expulsion-cirque-romanes (Accessed April 8, 2011).

European Roma Rights Center (2011) 'Rights Groups Demand Protection for Hungarian Roma.' Available at website of European Roma Rights Center http://www.errc.org/cikk.php? cikk=3816 (Accessed July 6, 2011).

European Union Agency for Fundamental Rights (2009) European Union Minorities and Discrimination Survey: Data in Focus Report - The Roma E(uropean Union Agency for Fundamental Rights). Available at: website of FRA - European Union Agency for Fundamental Rights. http://www.fra.europa.eu/fraWebsite/roma/roma_en.htm (Accessed July 6, 2011).

Fraser, Nancy (1990) 'Rethinking the Public Sphere: A Contribution to the Critique of Actually Existing Democracy' Social Text, No. 25/26, 56-80.

Gay, Peter (2001 [1968]) Weimar Culture: The Outsider as Insider (New York: Norton).

Harper, Krista, Tamara Steger and Richard Filčák (2009) 'Environmental Justice and Roma Communities in Central and Eastern Europe' Environmental Policy and Governance, Vol. 19, No. 4, 251-68.

Hungarian Ambiance (2011) 'Tension in Gyöngyöspata is Growing by the Minute'. Available at http://www.hungarianambiance.com/2011/03/tension-in-gyongyospata-is-growing-by.html (Accessed August 10, 2011).

Kalyi Jag (2008) 'Intézményi Minőségbiztosítási Program (IMIP)' (Institutional Quality-Assurance Program) Roma Nemzetiségi Szakiskola, Szakközépiskola és Alapfokú Müvészetoktatási Intézmény [Kalyi Jag Roma Nationality School and Primary Arts Education Institute]. Available at: website of Kalyi Jag School, "Dokumentumok" http://www.kalyijag.hu/ main.php?site=1\&id=7 (Accessed July 6, 2011).

Kligman, Gail, János Ladányi and Iván Szelényi (2002) 'A Note on the Meaning of "Underclass", Roma Rights No. 2, 112-14.

Ladányi, János and Iván Szelényi (2003) 'Historical Variations in Inter-ethnic Relations: Toward a Social History of Roma in Csenyéte’ Romani Studies, Vol. 13, No. 1, 1-51. 
Ladányi, János and Iván Szelényi (2005) 'Poverty after the Fall of State Stocialism’ The Analyst, Vol. 2, 125-40.

Ladányi, János and Iván Szelényi (2006) Patterns of Exclusion: Constructing Gypsy Ethnicity and the Making of an Underclass in Transitional Societies of Europe (Boulder, CO: East European Monographs).

Lange, Barbara Rose (1997) 'Hungarian Rom (Gypsy) Political Activism and the Development of Folklór Ensemble Music' The World of Music, Vol. 39, No. 3, 5-30.

Malvinni, David (2004) The Gypsy Caravan: From Real Roma to Imaginary Gypsies in Western Music and Film (New York and London: Routledge).

Markoff, Irene (2006) 'Roma Rule in the Chalga/Popfolk Groove.' Paper presented at the 51st Annual Meeting of the Society for Ethnomusicology (Honolulu, HI).

Molnár, Emilia and Csaba Dupcsik (2008) 'Country Report on Education: Hungary.' EDUMIGROM Background Papers. (Budapest: Central European University, Center for Policy Studies). Available at: EDUMIGROM Working Papers http://www.edumigrom.eu/working-papers (Accessed July 7, 2011).

Munk, Veronika (2007) “'Húzd rá, cigány!” A magyarországi roma sztárok reprezentációja' ('Play, Gypsy! The Representation of Hungarian Roma Stars). Ezredvég, Vol. 17, No. 1 (February). http://irodalom.elte.hu/ezredveg/0702/07024.html\#mv (Accessed April 1, 2011).

NOL (2011) 'Romagyilkosságok hidegvérrel, aprólékos forgatókönyvvel' (Roma Murders in Cold Blood, with Meticulous Script]. Népszabadság Online, March 25. Available at http://nol.hu/ belfold/romagyilkossagok_hidegverrel_aprolekos_forgatokonyvvel (Accessed April 10, 2011).

The Ogbu Family (2003) Biography. In Memory of John U. Ogbu. Available at http://www. ogbu.com/\#story (Accessed August 11, 2011).

Pogány, István (2004) The Roma Café: Human Rights \& the Plight of the Romani People (London: Pluto Press).

Puppinck, Gregor (2011) "FForced Sterilization” and Eugenism Before the European Court of Human Rights.' Website of European Centre for Law and Justice http://www.eclj.org/Releases/Read.aspx?GUID=152242ef-ec30-48a1-a7af-e93a35897453 (Accessed March 31, 2011).

Sárosi, Bálint (1978) Gypsy Music (Budapest: Corvina).

Sárosi, Bálint (1997) 'Hungarian Gypsy Music: Whose Heritage?’ The Hungarian Quarterly, No. 38 (147). Available at website of The Hungarian Quarterly http://www.hungarianquarterly. com/no147/p133.shtml (Accessed July 6, 2011).

Silverman, Carol (2007) 'Trafficking in the Exotic with "Gypsy” Music: Balkan Roma, Cosmopolitanism, and "World Music" Festivals' in Donna A. Buchanan (ed.) Balkan Popular Culture and the Ottoman Ecumene: Music, Image, and Regional Political Discourse (Lanham, MD: Scarecrow), 335-61.

Small, Mario Luis, David J. Harding and Michele Lamont (2010) 'Introduction: Reconsidering Culture and Poverty' The Annals of The American Academy of Political and Social Science Vol. $629,6-24$

Szalai, Júlia (2008) 'Ethnic Differences in Compulsory Education.' EDUMIGROM Policy Brief no. 1 (Budapest: Central European University, Center for Policy Studies). Available at: EDUMIGROM Policy Briefs http://www.edumigrom.eu/policy-briefs (Accessed July 6, 2011).

Szalai, Júlia (ed.) (2010) 'Being "Visibly Different": Experiences of Second-Generation Migrant and Roma Youths at School: A Comparative Study of Communities in Nine Member States of the European Union.' EDUMIGROM Comparative Papers (Budapest: Central European University, Center for Policy Studies). Available at: http://www.edumigrom.eu/working-papers (Accessed July 6, 2011). 
Szalai, Júlia (2011) 'Ethnic Differences in Education and Diverging Prospects for Urban Youth in an Enlarged Europe'. EDUMIGROM Summary Findings (Budapest: Central European University, Center for Policy Studies). Available at: EDUMIGROM Working Papers http://www. edumigrom.eu/working-papers (Accessed July 7, 2011).

Taylor, Timothy D. (1997) Global Pop: World Music, World Markets (New York-London: Routledge).

Vajda, Roza and Csaba Dupcsik (2008) 'Country Report on Ethnic Relations: Hungary.' EDUMIGROM Background Papers (Budapest: Central European University, Center for Policy Studies). Available at: EDUMIGROM Working Papers http://www.edumigrom.eu/working-papers (Accessed July 7, 2011).

van de Port, Martin (1999) 'The Articulation of Soul: Gypsy Musicians and the Serbian Other' Popular Music, Vol. 18, No. 3, 291-308.

Vermeersch, Peter (2006) The Romani Movement: Minority Politics \& Ethnic Mobilization in Contemporary Central Europe (New York-Oxford: Berghahn Books).

Warner, Michael (2001) 'Publics and Counterpublics' Public Culture, Vol. 14, No. 1, 49-90.

Wilson, William Julius (1987) The Truly Disadvantaged: The Inner-City, the Underclass, and Public Policy (Chicago: University of Chicago Press).

Yonas Media (2011) 'Little Cow' http://www.yonasmedia.com/ympress/littlecow/index.htm (Accessed April 7, 2011).

Zene a Rasszizmus Ellen (Music Against Racism) (2009) 'Rólunk' (About us) http://www.zare.hu/ about-us.php?lang=hu (Accessed August 10, 2011).

\section{Discography}

Bhattacharya, Deben (ed.) (1997) Zingari: Route of the Gypsies. Various artists. New Earth Records NE 9702-2.

Ensemble Caprice (2007) Vivaldi: The Baroque Gypsies. Analekta AN 29912.

Ensemble Caprice (2009) Telemann and the Baroque Gypsies. Analekta AN 29919.

Les Yeux Noirs (1992) Band of Gypsies. Buda Musique 82840-2.

Nascente (2001) Children of the Wind. Various artists. Nascente NSCD 078.

New Budapest Orpheum Society (2002) Dancing on the Edge of a Volcano: Jewish Cabaret, Popular, and Political Songs 1900-1945. Cedille Records CDR 90000065.

Rough Guides (1999) The Rough Guide to the Music of the Gypsies. Various artists. RGNET 1034 CD.

Scholze, Christian, Jean Trouillet and Alain Weber (ed.) (1996) Road of the Gypsies. Various artists. Network Medien 24.756.

Scholze, Christian (ed.) (1999) Gypsy Queens. Various artists. Network Medien 32.843.

Shapiro, Michael (ed.) (2001) Gypsy Caravan. Various artists. Putumayo PUT 185-2.

Taraf de Haïdouks (1994) Honourable Brigands, Magic Horses and Evil Eye. Cram World CRAW 13.

Taraf de Haïdouks (2001) Band of Gypsies. Nonesuch 79641-2.

Various artists (2001) Gypsy Magic: Nouveau Flamenco. EMI-Capitol Music 72435-32073-2-8. 